J. Perinat. Med. 17 (1989) 137

\title{
The value of ultrasonic placental grading: No correlation with intra- uterine growth retardation or with maternal smoking
}

\author{
Mieke B. J. G. Vosmar, Henk W. Jongsma, and Pieter W. J. van Dongen \\ Department of Obstetrics and Gynecology, University Hospital St. Radboud, \\ Nijmegen, The Netherlands
}

\section{Introduction}

For some years now, ultrasound has taken its place in the daily practice of prenatal care by obstetricians. Initially it was used as a method to assess gestational age and placental localization. Because of improvement of the technical equipment it also became possible to observe fetal behaviour in vivo. Ultrasound created the possibility to evaluate the placental tissue and its structure.

The first echoscopic description in placental tissue is from 1973 [28]: a distinction was made between homogenic and irregular placentae, which contained rounded transonic areas. Later specific changes in placental tissue were observed as pregnancy progressed [6]. A useful grading system (figures 1 and 2) was developed describing these ultrasonic changes of the placenta [8]. Originally the placental grading system was used as method of predicting fetal lung maturity. A $100 \%$ correlation $[8,19]$ was found between a Grade III placenta and a mature Lecithin/Sphingomyelin ratio. When other investigators $[2,5,10,13,21,24,25]$ found Grade III placentae in women, where according to the immature $\mathrm{L} / \mathrm{S}$ ratio or negative phosphatidylglycerol (PG) no fetal lung maturity could exist, more attention was paid to the possible relation between premature appearance of Grade III changes in placental tissue and intrauterine growth retardation (IUGR). Placentae of newborn infants who are small-for-gestational age (SGA) show more ischemic lesions (fibrin and calcium depositions, infarcts) $[1,3,26]$ than those in placentae of neonates who are appropriate for gestational age (AGA). Combined histological, radiological and ultrasound examination of the placenta showed that ultrasonic densities are caused by

\section{Curriculum vitae}

Mieke B. J. G. Vosmar was born in Ammerzoden, Holland. She studied medicine at the University of Nijmegen. During her study she spent half a year as student-doctor in Tanzania. From 1985 to 1987 she worked at the St. Radboud University Hospital in Nijmegen. In 1988 she started her residency in Obstetrics and Gynecology at the Groot Ziekengasthuis, 's-Hertogenbosch.

reticular calcification and fibrinoid degeneration $[6,8,9,12,26]$. Therefore one would expect an association between Grade III placentae and IUGR. Several studies pointed out the relation between the occurrence of a 'premature' Grade III and IUGR [6, 8, 9, 18, 20-23]. Kazzi et al. [14, 15] investigated the predictive value of a Grade III placenta in the growth-retarded fetus. A significant relationship was seen between a Grade III placenta and a SGA infant in a full term high-risk pregnancy group.

In order to study the usefulness of the placental grading by ultrasound, we decided to study this grading versus the outcome of the pregnancy, especially the occurrence of intrauterine growth retardation. Also the effect of smoking on pregnancy was evaluated, in order to investigate the possible relation between smoking and placental grading. 


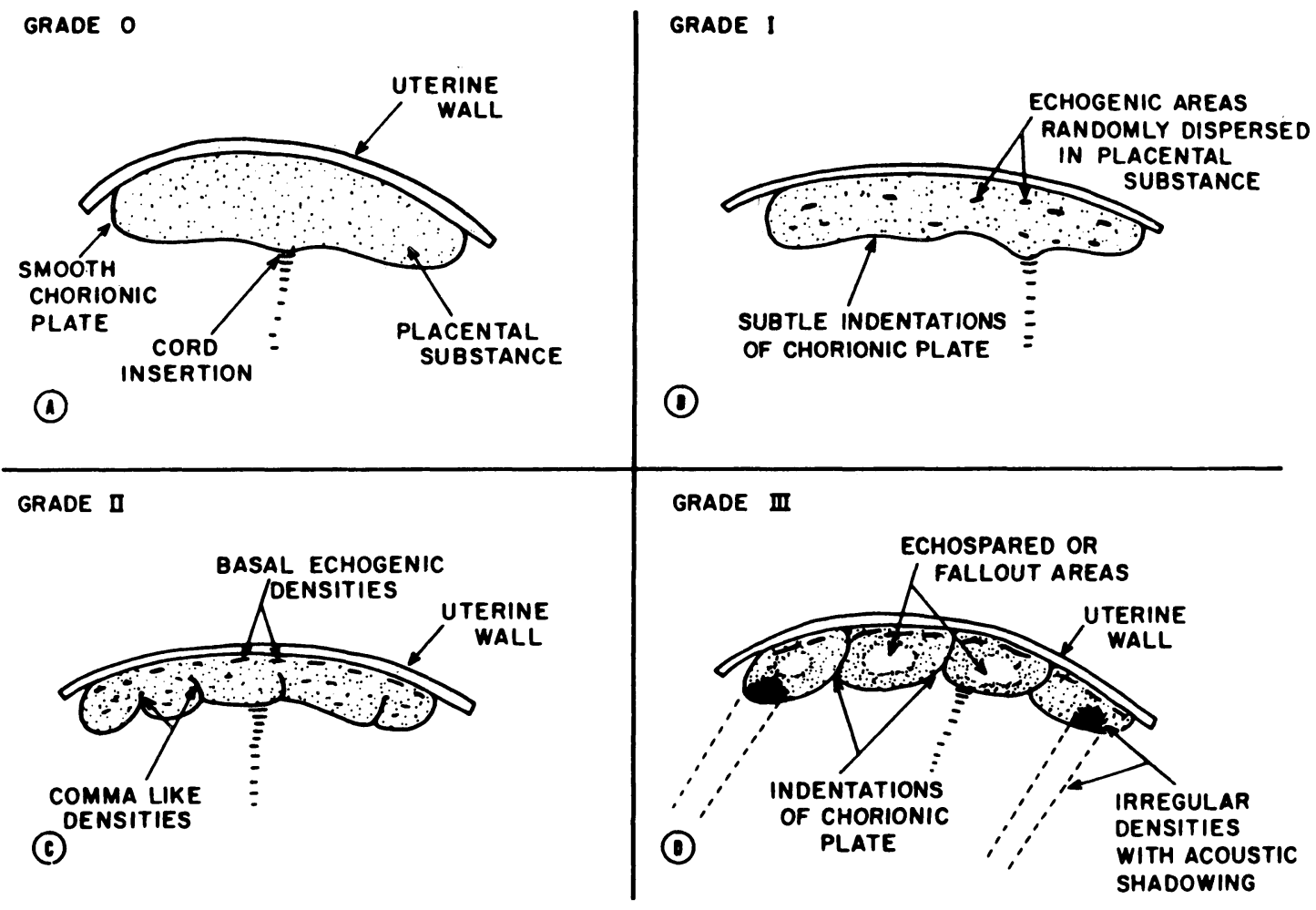

Figure 1. Schematic diagram illustrating the ultrasonic appearance of the four placental grades. (Reproduced with permission from Grannum [8]).

\section{Material and methods}

During September and October 1984, echoscopic observations were made in patients from a minimum of 26 weeks amenorrhoe onwards. These pregnant women were recruited from the outpatient department of Obstetrics of the St. Radboud University Hospital Nijmegen. All pregnant women planned to deliver within our investigation period were included.

The same two observers examined each patient with a Toshiba linear array realtime scanner with a $3.5 \mathrm{MHz}$ transducer. Patients who delivered within one week after examination were taken into this survey $(\mathbf{n}=137)$. An anterior or posterior placental location was noted when more than twothirds of the placental width was seen on the anterior or posterior uterine wall, respectively. The placenta was in a fundal location when in vertical plane one half of the placenta was on the anterior and the other half on the posterior wall of the uterus.
The placenta was ultrasonically graded according to the system described by Grannum et al. [8]. Whenever possible the entire placenta was evaluated. If in two different parts of the placenta two different grades were seen, the most mature part was noted.

Unaware of the given ultrasonic grade, all placentae were macroscopically examined and described within 24 hours post partum in a standardized way. The following grading system was used, presuming that the macroscopic structures are grossly comparable with the ultrasonic structures:

Grade 0: no calcium or fibrinoid depositions were seen and the placental surface was smooth.

Grade 1: some diffuse calcium and fibrinoid deposition.

Grade 2: beginning formation of septa, at the maternal side clear calcium deposition. 
GRADE O

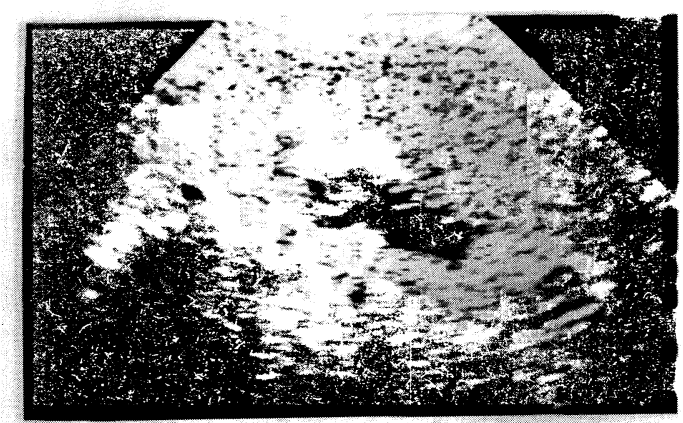

GRADE II

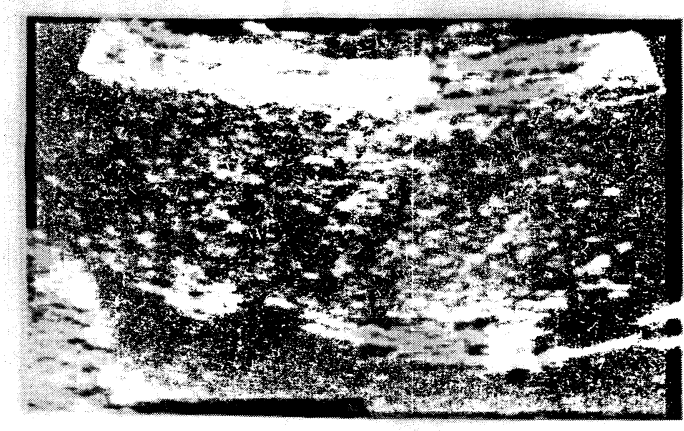

GRADE I

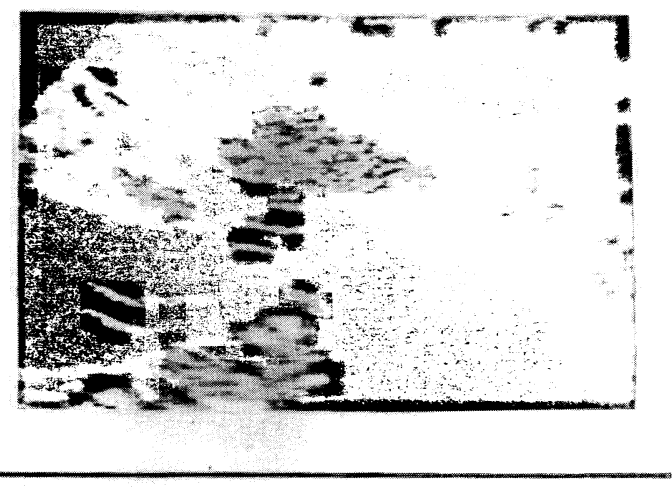

GRADE III

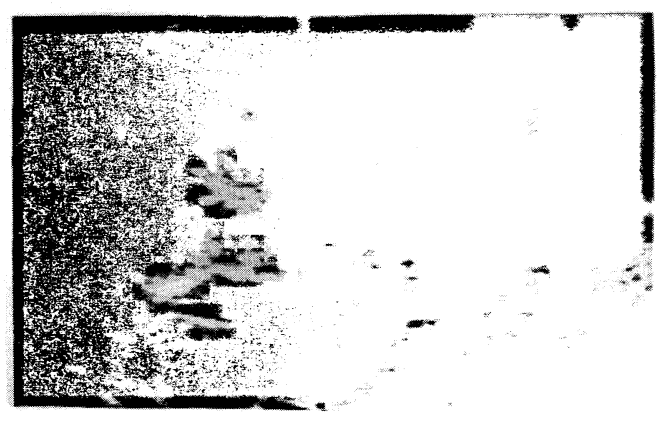

Figure 2. Ultrasonic appearance of the four placental grades.

Grade 3: cotyledons are present, a great number of calcium and fibrinoid deposition at the maternal and fetal sides, with infarcts and 'holes' by sectioning.

The smoking habit of each patient in every trimester was noted. A distinction was made between non-smokers, mild ( $<10$ cigarettes daily), moderate $(10-20$ cigs/day) and heavy smokers $(>20$ cigs/day).

In evaluating the relation between a Grade III and IUGR, a neonate was called SGA whose birth weight was less than the tenth birth weight percentile for the Dutch population, when gestational age, infant sex and parity were taken into consideration [16].

Statistical analysis was performed by means of Student's $t$, analysis of variance, Spearman rank correlation or $\mathrm{X}^{2}$ tests. A p of $<0.05$ was considered to be significant.

\section{Results}

A total of 595 ultrasonic evaluations of 176 patients were made within a period of 8 weeks. Patients seen within one week before delivery were taken into the study; 137 patients entered this survey and 39 patients were excluded due to not yet been delivered $(n=28)$, the last ultrasonic examination was more than one week prior to delivery $(n=7)$, ungradable placentae $(n=3)$ or because of unknown term $(n=1)$. In these 137 patients 466 examinations were made. The earliest gestational age was 26 weeks, the latest 43 weeks. All patients were seen every time they visited the outpatients department or weekly when they were admitted in the wards. The maximum of examinations performed in one patient was 7 .

In $53.3 \%(73 / 137)$ the placenta could entirely be evaluated on ultrasonic examination. In the remaining group not all parts of the placenta could 
be seen, but enough to be graded. Separate analysis of the two groups showed no statistical differences in the results of this study. Therefore, the 137 subjects were considered as belonging to one group only. Of the 137 patients in our study, 76 $(55.5 \%)$ had an anterior, $46(33.6 \%)$ a posterior placental location and $14(10.2 \%)$ had a fundal placenta. Placental morphology and placental grading were significantly correlated (Spearman rank correlation coeff. $0.77, \mathrm{p}=0.0001$ ). There was an agreement between placental grading and placental morphology with an accuracy of $80.5 \%$ (table I).

Table I. Correlation of macroscopic examination post partum and placental grading.

\section{Placental morphology}

$\begin{array}{lllllll}\text { Placental } & 0 & 1 & 2 & 3 & \text { unknown* } & \text { correct }\end{array}$ grade

\begin{tabular}{lrrrrrr}
\hline 0 & 10 & 2 & 2 & 2 & 0 & $62.5 \%$ \\
I & 0 & 26 & 5 & 9 & 3 & $65.0 \%$ \\
II & 0 & 0 & 16 & 2 & 3 & $88.9 \%$ \\
III & 0 & 0 & 3 & 51 & 1 & $94.4 \%$ \\
\hline
\end{tabular}

Accuracy

$80.5 \%$

* accidentally destroyed

In this study population a significant relationship was found between increasing placental grading and gestational age (figure 3 ). In all five cases of post datism (gestational age $>42$ weeks) a Grade III was seen. In 57 cases $(41.6 \%)$ pregnancy ended with a Grade III placenta; only five before 37 weeks of gestational age and five times after 42 weeks. Thus the incidence of Grade III placenta at term was $34 \%(47 / 137)$.

Comparing the Grade III placenta group with the non-Grade III placenta group, no significant association could be found in the prevalence of children who were small-for-gestational age (table II). Thus no predictive value was present for a Grade III placenta and a subsequent SGA-delivery. However, three out of five cases before 35 weeks of pregnancy with a Grade III placenta showed an IUGR.

Placental grading and smoking. There were 134 pregnancies with known smoking habits in every trimester. Data on birth weight, placental weight and placental ratio (placental weight/birth weight) are given in table III.

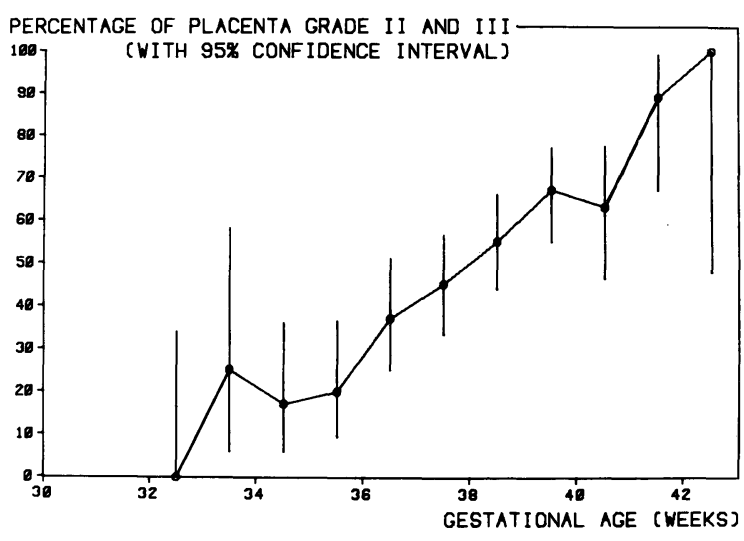

Figure 3. The relation between placental grading and increasing gestational age, for grades II and III only.

Table II. Contingency table showing Grade III placenta in relation with IUGR (SGA, $\mathrm{p}<10$ ).

\begin{tabular}{lccc}
\hline Placental grade & SGA & AGA & Total \\
\hline Grade III & 7 & 50 & 57 \\
Non-Grade III & 11 & 69 & 80 \\
Total & 18 & 119 & 137 \\
\hline
\end{tabular}

$\mathrm{X}^{2}=3.5, \mathrm{p}=0.32$ (not significant)

$\mathrm{SGA}=$ small for gestational age

$\mathrm{AGA}=$ appropriate for gestational age

Table III. The effect of mothers smoking habit on birth weight, placental weight and placental ratio $(n=134)$.

\begin{tabular}{lrllll}
\hline Smoking habit & $\mathrm{n}$ & $\begin{array}{l}\text { Mean birth* } \\
\text { weight (g) }\end{array}$ & $\begin{array}{l}\text { Mean pla- Placen- } \\
\text { cental** } \\
\text { weight (g) }\end{array}$ & $\begin{array}{l}\text { rat*** } \\
\text { ratio }\end{array}$ \\
\hline Non-smokers & 75 & $3408(536)$ & $507(106)$ & 0.149 \\
$<10$ cigs/day & 18 & $3213(589)$ & $446(97)$ & 0.140 \\
$10-20$ cigs/day & 32 & $3074(613)$ & $473(93)$ & 0.156 \\
$>20$ cigs/day & 9 & $3167(379)$ & $512(103)$ & 0.161 \\
\hline
\end{tabular}

0 : standard deviation

${ }^{*} \mathrm{p}=0.03 ;{ }^{* *} \mathrm{p}=0.08,{ }^{* * *} \mathrm{p}=0.06$ (one way analysis of variance)

The sample showed $44 \%$ smokers. The mean birth weight decreased significantly the more they smoked $(p=0.03)$, but there was no significant difference among the mean placental weights and placental ratio. In comparing the placental ratios, a trend could be detected $(p=0.06)$ that as the amount of smoking increased, the placental ratio increased as well. 
The effect of smoking on birth weight may be complicated by differences in age, parity, sex and gestational age between the three smoking groups. Regarding both gestational age and maternal age there was no difference between these three groups. To eliminate the effects of sex and parity on birth weight, the effect of smoking or not smoking on the birth weight percentile was evaluated (table IV). If the pregnant woman smoked then the birth weight percentile decreased significantly $(p=0.0008)$.

No relation was found between the effect of smoking on placental grading (table V) (Spearman rank correlation coefficient $0.007 ; \mathrm{p}=0.93$ ).

Table IV. The effect of smoking on the birth weight percentile.

\begin{tabular}{lll}
\hline $\begin{array}{l}\text { Birth weight } \\
\text { percentile }\end{array}$ & $\begin{array}{l}\text { non-smokers } \\
\mathrm{n}\end{array}$ & $\begin{array}{l}\text { smokers } \\
\mathrm{n}\end{array}$ \\
\hline$<\mathrm{p} 10$ & 6 & 11 \\
p10-p50 & 23 & 31 \\
> p50 & 46 & 17 \\
Total & 75 & 59 \\
\hline
\end{tabular}

$\mathrm{X}^{2}=14.3, \mathrm{p}=0.0008$

Table V. Effect of smoking on placental grading $(n=134)$.

\begin{tabular}{lrrrrl}
\hline & \multicolumn{7}{c}{ Placental grading } \\
\cline { 2 - 6 } Smoking habit & \multicolumn{1}{c}{0} & \multicolumn{1}{c}{ I } & II & III & Total \\
\hline Non-smokers & 10 & 24 & 7 & 34 & 75 \\
< 10 cigs/day & 1 & 8 & 4 & 5 & 18 \\
$\geqslant 10$ cigs/day & 5 & 10 & 9 & 17 & 41 \\
\hline
\end{tabular}

\section{Discussion}

In this prospective study the placental grade was correlated with the outcome of pregnancy in order to determine its usefulness for predicting IUGR. Previous reports were concentrated upon high risk patients. In this survey an unselected high and low risk population was investigated.

Changes in placental tissue increased clearly as pregnancy progressed and $42 \%(57 / 137)$ of the placentae reached Grade III. The discrepancy in the incidence of Grade III at term (34\%), com- pared to other studies (15\% [8], $20 \%$ [11]), could be related to the strict criteria kept in this study for the determination of the placental grade according to Grannum [7]. In spite of those criteria, placental grading still remains a subjective interpretation of an echoscopic picture; accurate instruction and interpretation is necessary.

Post partum examination of the placentae correlated well with the ultrasound grading, so the ultrasonic image is likely to be the in vivo representation of the placenta.

Much value has been attributed to the ultrasound assessment of the biophysical profile to improve the quality of perinatal care [17]. As an extra item Vintzileos et al. [27] added the placental grading to the biophysical profile. Key finding in our survey is that ultrasonic determination of a Grade III placenta at term is not helpful in predicting IUGR. However, one may suggest that the premature occurrence of Grade III placenta might predict IUGR.

There have been many reports on the effect of smoking in pregnant women, proving that smoking causes growth retardation of the fetus. We can confirm this observation. The relation between smoking and placental weight is more controversial. Christianson [4] found a striking higher prevalence of calcification and subchorionic fibrin deposits in the placentae of smokers as compared to non-smokers. The placentae of smokers were also heavier. These and other observations suggest that in placentae of smokers an acceleration exists of the normal aging process of the placenta. As increasing placental grading represents the normal maturation process of the placenta, a relation was expected between the amount of cigarette consumption and placental grading. This couldn't be confirmed, may be due to the small number of heavy smokers.

\section{Conclusions}

1. Increasing placental grading is associated with normal maturation of the placenta.

2. In an unselected term group there is no relation between Grade III placenta and IUGR.

3. Smoking correlates well with a decrease in birth weight, but not with an accelerated placental grading. 


\section{Summary}

In a prospective study the usefulness of placental grading in detecting IUGR has been evaluated. Those who were echoscopically examined within one week before delivery were taken into the study $(n=137)$. Changes in placental tissue increased clearly as pregnancy progressed and in $42 \%(57 / 137)$ the placentae reached Grade III. Increasing placental grading is associated with normal maturation of the placenta. Post partum examination of the placenta correlated well with the echoscopic picture (accuracy $=80.5 \%)$. No relationship was found in an unselected group between Grade III and IUGR at term.
When a Grade III placenta was first seen before 36 weeks, in three out of five cases a growth retarded neonate was born.

The effects of maternal smoking habits during pregnancy on birth weight and placenta were examined. There were no significant differences in mean placental weight, placental ratio and placental grading as the amount of cigarettes increased. The mean birth weight and birth weight percentile decreased significantly when the mother smoked more than 10 cigarettes per day.

Keywords: Intrauterine growth retardation, placental grading, smoking, ultrasound.

\section{Zusammenfassung}

Sonographisches Grading der Plazenta: keine Korrelation mit intrauteriner Wachstumsretardierung oder mütterlichem Rauchen

In einer prospektiven Studie wurde untersucht, ob ein Grading der Plazenta zur Aufdeckung einer intrauterinen Wachstumsretardierung (IUGR) sinnvoll ist. Alle innerhalb einer Woche vor Entbindung sonographisch untersuchten Patientinnen wurden in die Studie aufgenommen $(n=137)$. Veränderungen des Plazentagewebes nahmen mit fortschreitendem Schwangerschaftsalter deutlich zu und in 42\% (57/137) erreichte die Plazenta Grad III. Die Zunahme des Gradings ist mit der normalen Reifung der Plazenta assoziiert. Untersuchungen der Plazenta post partum korrelierten gut mit dem so- nographischen Bild (Genauigkeit $=80.5 \%$ ). In einem unselektierten Kollektiv zeigte sich kein Zusammenhang zwischen einem Grad III und einer IUGR am Termin. Wurde eine Plazenta mit Grad III vor der 36. Schwangerschaftswoche gesehen, kam es in drei von fünf Fällen zur Geburt eines wachstumsretardierten Neugeborenen. Wir untersuchten die Auswirkungen von mütterlichem Rauchen während der Schwangerschaft auf das Geburtsgewicht und die Plazenta. Eine Zunahme des Nikotinabusus beeinflußte das mittlere Plazentagewicht, die Plazenta-Ratio sowie das plazentare Grading nicht signifikant. Es kam jedoch zu einem deutlichen Abfall des mittleren Geburtsgewichtes und der Geburtsgewichtsperzentile bei mehr als 10 Zigaretten pro Tag.

Schlüsselwörter: Intrauterine Wachstumsretardierung, plazentares Grading, Rauchen, Ultraschall.

\section{Résumé}

Valeur du grading placentaire échographique: absence de corrélation avec le retard de croissance intra-uterin et avec le tabagisme maternel

On a évalué dans une étude prospective l'utilité d'un classement placentaire pour le dépistage du RCIU.

Ont été pris dans l'étude des patientes qui avaient subi une échographie au cours de la dernière semaine précédant l'accouchement (n: 137). Il y a une augmentation des modifications du tissu placentaire avec l'évolution de la grossesse et dans $42 \%$ des cas (57/137) les placentas attaignent le grade III.

L'augmentation du grade placentaire s'accompagne d'une maturation normale du placenta. L'examen postpartum du placenta est bien corrélé avec les images échographicques (fiabilité: 80,5\%).
On n'a pas trouvé de corrélation dans un groupe non sélectionné entre le grade III et le RCIU à terme.

Lorsqu'un placenta de grade III est observé avant la 36 ème semaine, dans 3 des 5 cas, il y a eu naissance d'un enfant hypotrophique.

On a éxaminé les effets tu tabagisme maternel pendant la grossesse sur le poids de naissance et sur le placentá. Il n'y pas de différences significatives entre le poids placentaire moyen, le ratio placentaire et le grade placentaire, avec l'élévation du nombre de cigarettes.

Le poids de naissance moyen et le percentile du poids de naissance diminuent de façon significative lorsque la mère fume plus de 10 cigarettes par jour.

Mots-clés: Classification placentaire, retard de croissance intra utérin, tabagisme, ultrasons. 


\section{References}

[1] Altshuler G, P Russel, R Ermocilia: The placental pathology of small-for-gestational age infants. Am J Obstet Gynecol 121 (1975) 351

[2] Ashton SS, MP Russo, NV Simon, DM Shearer: Relationship between Grade III placentas and biparietal diameter determinations. J Ultrasound Med 2 (1983) 127

[3] BERNISCHKE K: Examination of the placenta. Obstet Gynecol 18 (1961) 309

[4] Christianson RE: Gross differences observed in the placentas of smokers and nonsmokers. Am J Epidemiol 110 (1979) 178

[5] Clair Mr, E Rosenberg, D Tempkin, RF ANDREOTTI, JD BowIE: Placental grading in the complicated or high-risk pregnancy. J Ultrasound Med 2 (1983) 297

[6] Fisher CC, W Garrett, G Kossoff: Placental aging monitored by gray scale echography. Am J Obstet Gynecol 124 (1976) 483

[7] GRANNUM PAT: Ultrasound examination of the placenta. Clinics in Obstetrics and Gynecology 10 (1983) 459

[8] Grannum PAT, RL Berkowitz, JC Hobbins: The ultrasonic changes in the maturing placenta and their relation to fetal pulmonic maturity. Am J Obstet Gynecol 133 (1979) 915

[9] HANEY AF, WS Trought: The sonolucent placenta in high-risk obstetrics. Obstet Gynecol 55 (1980) 38

[10] Harman CR, FA Manning, E Stearns, I MorriSON: The correlation of ultrasonic placental grading and fetal pulmonary maturation in five hundred sixty-three pregnancies. Am J Obstet Gynecol 134 (1982) 941

[11] Hill LM, R Breckle, MW Ragozzino, KR WolfGRAM, PC O'BRIEN: Grade 3 placentation: Incidence and neonatal outcome. Obstet Gynecol 61 (1983) 728

[12] Uwamoto VM, T Hashimoto, T Tsuzaki, K MAEDA: Ultrasonographic study of the placenta in vitro. Gynecol Obstet Invest 11 (1980) 265

[13] Kazzi GM, TL Gross, MG Rosen, NY JaAtoulKAZZI: The relationship of placental grade, fetal lung maturity and neonatal outcome in normal and complicated pregnancies. Am J Obstet Gynecol 148 (1984) 54

[14] Kazzi GM, TL Gross, RJ SoKol: Fetal biparietal diameter and placental grade: Predictors of intrauterine growth retardation. Obstet Gynecol 62 (1983) 755

[15] Kazzi GM, TL Gross, RJ Sokol, NJ Kazzi: Detection of intrauterine growth retardation: a new use for sonographic placental grading. Am J Obstet Gynecol 145 (1983) 733
[16] Kloosterman GJ: De voortplanting van de mens. Centen. Haarlem 1977

[17] Manning FA, LD Platt, L Sipos: Antepartum fetal evaluation. Development of a fetal biophysical profile score. Am J Obstet Gynecol 136 (1980) 787

[18] Patterson RM, RH Hayashi, D Cavazos: Ultrasonographically observed early placental maturation and perinatal outcome. Am J Obstet Gynecol 147 (1983) 773

[19] Petrucha RA, SH Golde, LD Platt: Real-time ultrasound of the placenta in assessment of fetal pulmonic maturity. Am J Obstet Gynecol 142 (1982) 463

[20] Petrucha RA, LD Platt: Relationship of placental grade to gestational age. Am J Obstet Gynecol 144 (1982) 733

[21] QUINLAN RW, AC CRUZ: Ultrasonic placental grading and fetal pulmonary maturity. Am J Obstet Gynecol 142 (1982) 110

[22] Quinlan RW, AC Cruz, WC Buhi, M Martin: Changes in placental ultrasonic appearance. I. Incidence of Grade III changes in the placenta in correlation to fetal pulmonary maturity. Am J Obstet Gynecol 144 (1982) 468

[23] Quinlan RW, AC Cruz, WC Buhi, M Martin: Changes in placental ultrasonic appearance. II. Pathologic significance of Grade III placental changes. Am J Obstet Gynecol 144 (1982) 471

[24] Ragozzino MW, LM Hill, R BRECKLE, RD ELLEFSON, RC SMITH: The relationship of placental grade by ultrasound to markers of fetal lung maturity. Radiology 148 (1983) 805

[25] TABSH KMA: Correlation of real-time ultrasonic placental grading with amniotic fluid lecithin/sphingomyelin ratio. Am J Obstet Gynecol 145 (1983) 504

[26] VANDENBERGHE K: Ultrasonography of the placenta. J Perinat Med (Suppl 1) 9 (1981) 75

[27] Vintzileos AM, WA CAMPBell, CJ INGardia, DJ Nochimson: The fetal biophysical profile and its predictive value. Obstet Gynecol 62 (1983) 271

[28] WINSBERG F: Echographic changes with placental ageing. J Clin Ultrasound 1 (1973) 52

Received April 3, 1987. Revised November 11, 1988. Accepted January 12, 1989.
M. B. J. G. Vosmar
Department of Obstetrics and Gynaecology
St. Radboud Hospital
P. O. Box 9101
6500 HB Nijmegen
The Netherlands 